\title{
MERCURY EXPOSURE: NOVEL THERAPEUTIC APPROACHES
}

\author{
RADU CIPRIAN ȚINCU ${ }^{1,2}$, CRISTIAN COBILINSCHI ${ }^{3}$, OANA ANDREIA COMAN ${ }^{4}$, \\ LAURENŢIU COMAN $^{5}$, IULIA FLORENTINA ŢINCU ${ }^{6,7 *}$, RADU ALEXANDRU MACOVEI $^{1,2}$
}

${ }^{1}$ Critical Care Toxicology Unit, Clinical Emergency Hospital Bucharest, Romania

${ }^{2}$ Discipline of Toxicology, Department of Orthopaedics - Anaesthesiology and Intensive Care, Faculty of Medicine, "Carol Davila" University of Medicine and Pharmacy, Bucharest, Romania

${ }^{3}$ Anesthesiology Intensive Care Unit, Clinical Emergency Hospital Bucharest, Romania

${ }^{4}$ Discipline of Pharmacology and Pharmacotherapy, Faculty of Medicine, "Carol Davila" University of Medicine and Pharmacy, Bucharest, Romania

${ }^{5}$ Physiology Department, Faculty of Pharmacy, "Carol Davila” University of Medicine and Pharmacy, Bucharest, Romania

6 "Dr. Victor Gomoiu” Clinical Children Hospital, Bucharest, Romania

${ }^{7}$ Discipline of Paediatrics, Department of Paediatrics and Genetics, Faculty of Medicine, "Carol Davila" University of Medicine and Pharmacy, Bucharest, Romania

*corresponding author: if_boian@yahoo.com

Manuscript received: February 2020

\begin{abstract}
In the past decade, it has been a focus on chronic, low or moderate exposure to methylmercury and some randomized control trials draw the attention on health implications of low-grade mercury toxicity. This study was aimed to evaluate efficacy of a combined treatment in mercury exposed patients. Subjects were randomized to receive chelation therapy alone or chelation therapy associated with a combination of Silybum marianum (172 mg), N-Acetyl-Cysteine (200 mg), L-Glutathione (25 mg), Vitamin C (120 mg), Selenium $(100 \mu \mathrm{g})$, Helianthus tuberosus, Taraxacum officinale, Schisandra chinensis, Zingiber officinale, Citrus paradise (an already on use formula), respectively. A total of 300 patients were equally randomized in 2 groups. Patients in the intervention group had significantly lower levels of mercury after 30 days of treatment, as well as after 30 days since the treatment has stopped $(6.1 \pm 4.4 v s .7 .6 \pm 4.0, \mathrm{p}=0.002$ and $3.8 \pm 3.0 v s .5 .5 \pm 3.3, \mathrm{p}=0.000$, respectively). This study provides evidence regarding some herbal extracts that may play a protective role against mercury toxicity, improving clinical scores when compared to standard treatment. More trials are needed to establish an integrative approach against mercury poisoning.
\end{abstract}

\section{Rezumat}

Intoxicația cu mercur a fost abordată, în ultimul deceniu, sub aspectul expunerii cronice, chiar la nivel scăzut sau moderat, iar unele studii randomizate au atras atenția asupra implicațiilor toxice ale unui nivel scăzut de mercur. Studiul de față are drept obiectiv evaluarea eficacității unui tratament combinat la pacienții expuși la mercur. Subiecții au fost randomizați pentru a primi terapie de chelare sau terapie de chelare asociată cu o combinație de Silybum marianum (172 mg), N-acetil-cisteină (200mg), L-Glutation (25 mg), Vitamina C (120 mg), Seleniu (100 mcg), Helianthus tuberosus, Taraxacum officinale, Schisandra chinensis, Zingiber officinale, Citrus paradis (o formulă deja în uz), respectiv. Au fost incluși 300 de pacienți. Pacienții din grupul de intervenție au avut un nivel semnificativ mai scăzut de mercur după 30 de zile de tratament, precum şi după 30 de zile de la încetarea tratamentului $(6,1 \pm 4,4$ vs. 7,6 $\pm 4,0, p=0,002$ și 3,8 $\pm 3,0 v s .5,5 \pm 3,3, p=0,000$, respectiv). Acest studiu oferă dovezi cu privire la beneficiile unor fitoextracte care pot juca un rol protector împotriva toxicității mercurului, îmbunătățind scorurile clinice în comparație cu tratamentul standard. Sunt necesare studii suplimentare pentru a stabili o abordare integrativă împotriva intoxicației cronice cu mercur.

Keywords: mercury, toxicity, low level exposure

\section{Introduction}

There is a history of 3000 years of using mercury $(\mathrm{Hg})$ by human kind. The main areas of its use are making thermometers, barometers, manometers, whitening cosmetics, and dental amalgam. Nowadays, we face lower levels of poisoning due to occupational mercury intoxication, as a consequence of implemented legislation that supervises the inhalation of metal and inorganic mercury compounds in workplaces. Nevertheless, cases of exposure to mercury in various occupations still exist and treatment is required. In the past decade, it has been a focus on chronic, low or moderate grade of exposure, often regarded as a topic of great controversy, excluding high concentration of methylmercury exposure and some randomized control trials draw the attention on health implications of lowgrade mercury exposure. In the meantime, therapeutic attitude of this kind of mercury intoxication has received little research attention. Pathogenic toxicity mechanisms depend on the characteristics of different mercury forms, as it may occur in several forms 
FARMACIA, 2020, Vol. 68, 4

including metallic, inorganic, and organic compounds [1]. There is heterogeneity in mercury exposure epidemiology, with 1300 single mercury exposures stated by the United States in 2013 and much higher rates in Chinese population, in the Iraqi people eating bread baked with grain that was treated with methylmercury based fungicide or in the Japanese eating the fish containing methylmercury [2].

There are no epidemiologic data in our country, but we deal with some particular practices involving occult rituals using elemental mercury that consist in drinking liquids with mercury, provided by traditional Romanian witchcraft. Although in Romania there are no places to buy mercury or other products for occult rituals, this type of practice using mercury is highly popular, and approximately 200 cases are admitted per year in the Intensive Care-Toxicology Unit of the Clinical Emergency Hospital in Bucharest [3].

All types of mercury chronic exposure alter sooner or later various biochemical parameters, such as liver and kidney function or lipid and protein metabolism. An important mechanism is considered to be the significant rise in the lipid peroxidation level that involves reducing the antioxidant enzymes activities. There is consent for symptomatic patients with mercury poisoning that they need immediate chelating therapy, although it is not fully understood whether these agents are truly beneficial in severely intoxicated patients. Even so, therapeutic efficacy in order to decrease morbidity and mortality is widely unestablished in cases of chronic metal intoxication [4]. Chelating agents that can be used for acute inorganic mercury poisoning are: dimercaprol (British Anti-Lewisite, BAL), D-penicillamine (DPCN), dimercaptopropane sulfonate (DMPS), and succimer (dimercaptosuccinic acid, DMSA) [5]. Nowadays, there is evidence that some natural antioxidants play a protective role against mercury-derived toxicity [6]. Thus, this study was aimed to evaluate the efficacy of a combined treatment in mercury exposed patients.

\section{Materials and Methods}

\section{Study design}

The design of this trial was two-armed, randomized, unblind, controlled, consisting of 30 days of treatment and 30 days of follow-up. The two arms consisted of two treatment groups, treated with chelation therapy (control group) and chelation therapy with a standard combination of Silybum marianum (172 mg), NAcetyl-Cysteine (200 mg), L-Glutathione (25 mg), Vitamin C (120 mg), Selenium $(100 \mu \mathrm{g})$, Helianthus tuberosus, Taraxacum officinale, Schisandra chinensis, Zingiber officinale, Citrus paradise (intervention group), respectively that was given orally, 2 capsules per day. This combination covers multiple pathogenic mechanisms involved in intoxication, such as: oxidative pathways, depletion of antioxidant precursors, decrease in the hepatic detoxification capacity, increase of lipid peroxidation. Chelation therapy consisted in 2,3-dimercapto-1-propanesulfonic acid $600 \mathrm{mg}$ orally, daily. Randomization was done into the treatment arms in equal numbers to obtain a 1:1 ratio.

Subjects

The study subjects were recruited from Intensive Care-Toxicology Unit of the Clinical Emergency Hospital in Bucharest, were they were admitted for mercury exposure. For inclusion in the study, only subjects with the following criteria were taken into consideration: age between 18 and 65 years, plasma$\mathrm{Hg}<40 \mu \mathrm{g} / \mathrm{L}$, a mercury intoxication medical score of $\geq 5$ or $\geq 3$ in combination with at least two of the additional symptoms social nervousness/withdrawal, irritability, memory loss, metallic taste, mental and physical fatigue, as used in similar studies [7]. We excluded all individuals suffering of chronic illnesses that may affect biologic parameters plasma levels, such as liver or kidney conditions, or those with professional intoxication that could not end their chronic exposure. The ethics committee of the Clinical Emergency Hospital approved this study and a written informed consent was obtained from each participant. Recorded data included clinical evaluation on admission regarding nervousness/withdrawal, irritability, memory loss, metallic taste, mental and physical fatigue. Blood samples were obtained during the admission procedure, collected following standard guidelines, in order to evaluate mercury blood levels at baseline, after 30 days of treatment and after other 30 days since the treatment has stopped.

\section{Outcomes}

The main outcome was defined as the difference in the mercury level in the 2 groups, from baseline to the end of the study ( 3 endpoints of blood assessment). As secondary outcomes, we considered the mercury intoxication medical score (MIS), mental fatigue score (MFS) and physical fatigue score (PFS).MIS is a useful clinical tool that identifies mercury intoxication in patients. It is a ten-point score which is assessed through medical examination, neuro-motor testing and medical interview $[8,9]$. Each item can have an assigned value of 0 or 1 , depending on whether the symptom is absent (0) or present (1) or whether the test result is negative (0) or positive (1). The change value for the score ranges from - 10 (maximal improvement of symptoms) to 8 (maximal worsening of symptoms), since the least score for subject inclusion is 2 . The MIS score was assessed at baseline, visit day 30 and visit day 60 [7]. MFS and PFS consist of 13 items regarding physical fatigue [8] and mental fatigue [5], scored according to literature data: "better or much better than usual" (0), "same as usual" (1), "worse than usual" (2) and "much worse than usual" (3) [10]. Accordingly, the higher the score is, the worse the fatigue is. Those scores were performed at baseline, visit day 30 and visit day 60 . 
Statistical analysis

Statistical analysis was performed by Statistical Package for Social Sciences (SPSS) version 18.0. Descriptive statistics was used to present variables. Continuous variables were expressed as median value. The results of the two treatment groups were separately compared using tests for differences between the groups: analysis of co-variance (ANCOVA) method, adjusting for baseline level, for parametric distributed characteristics, and the Wilcoxon-Mann-Whitney test for non-parametric results. Statistical significance was set for a $\mathrm{P}$ value less than 0.05 .

\section{Results and Discussion}

The baseline characteristics of the participants are shown in Table I. There was no difference in terms of age, BMI, working exposed area and plasma mercury between the two groups. Occult rituals were incriminated in 82 cases as the source of exposure, 110 declared consuming fish at least once week and the remaining patients were professional chronic exposures.

Table I

Baseline characteristics of the study population

\begin{tabular}{cccc}
\hline Variable & Control group $(\boldsymbol{n}=\mathbf{1 5 0})$ & Intervention group $(\boldsymbol{n}=\mathbf{1 5 0})$ & $\mathbf{p}$-value \\
\hline Age (years) & $47.6 \pm 12.3$ & $38.5 \pm 11.2$ & $\mathrm{NS}$ \\
BMI $\left(\mathbf{k g} / \mathbf{m}^{2}\right)$ & $24.8 \pm 3.4$ & $26.1 \pm 3.2$ & $\mathrm{NS}$ \\
Living in the mining area (years) & $1.3 \pm 0.3$ & $1.5 \pm 0.4$ & $\mathrm{NS}$ \\
Working with mercury (years) & $1 \pm 0.9$ & $1.5 \pm 0.8$ & $\mathrm{NS}$ \\
$\begin{array}{c}\text { Fish Consumption } \\
\text { At least once a week }\end{array}$ & $108(72.2 \%)$ & $102(68.5 \%)$ & $\mathrm{NS}$ \\
Never or less than once a week & $42(27.8 \%)$ & $48(31.5 \%)$ & $\mathrm{NS}$ \\
$\begin{array}{c}\text { Mercury plasma level } \\
\text { (baseline, } \boldsymbol{\mu g} / \mathbf{L})\end{array}$ & $11.04 \pm 6.1$ & $10.14 \pm 6.08$ & $\mathrm{NS}$ \\
\hline
\end{tabular}

Figures 1 and 2 summarize the mean mercury in plasma values for the study groups; patients in the intervention group had significantly lower levels of mercury after 30 days of treatment, as well as after

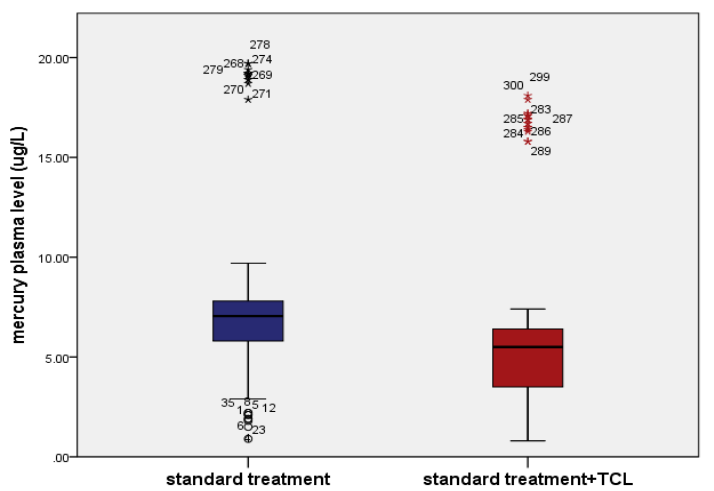

Figure 1.

Mean mercury plasma level after 30 days
30 days since the treatment has stopped $(6.1 \pm 4.4 \mathrm{vs}$. $7.6 \pm 4, \mathrm{p}=0.002$ and $3.8 \pm 3$ vs. $5.5 \pm 3.3, \mathrm{p}=0.000$, respectively).

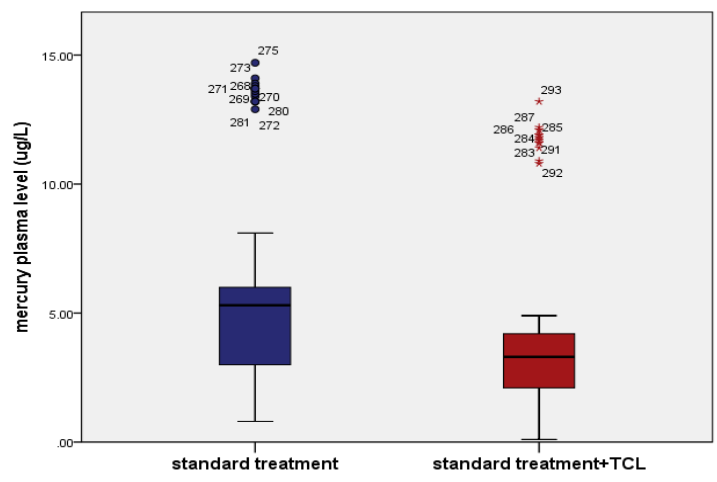

Figure 2.

Mean mercury plasma level after 60 days

TCL - a combination of Silybum marianum (172 mg), N-Acetyl-Cysteine (200 mg), L-Glutathione (25 mg), Vitamin C (120 mg), Selenium $(100 \mu \mathrm{g})$, Helianthus tuberosus, Taraxacum officinale, Schisandra chinensis, Zingiber officinale, Citrus paradise

At baseline, the 2 groups had similar median MIS, PFS and MFS (Table II). At first check-up visit, on day 30, the majority of all participants experienced a decrease in the above mentioned scores compared to the enrolment. The mean change was -3.5 points for the intervention and -2 for the standard arm. The differences between the treatment arms were assessed based on the ANCOVA methods, and the evolution was significant for the intervention group. As general recommendations, chelating agents are used in order to bind $\mathrm{Hg}$ molecules and lower their toxicity. Nevertheless, this is the first study in our country designed to gather and monitor various outcomes of plant extracts in mercury exposed patients. Despite being unblind, a positive effect could be shown. The most evident effect of combined treatment compared to standard treatment was on the subjects' fatigue. The physical fatigue score was improved in the combined group, even in the first month after baseline, and continued to decrease at follow up. Considering that oxidative stress is one of the major pathogenic pathways in mercury exposure, increased 
FARMACIA, 2020, Vol. 68, 4

exogenous antioxidant supplementation has been found to be effective in combating those effects $[11,14]$. An experimental study using one of the components included in our research formula showed that treatments with Zingiber officinale extract and 6-gingerol provided protection against acute mercuric chloride-intoxication by preventing oxidative degradation of a biological membrane from metal mediated free radical attacks [12]. It is desirable to take into account the potential herbal treatments for the heavy metals poisoning due to their fewer side effects [13].

Table II

Median scores and ranges at baseline, day 30 and day 60

\begin{tabular}{ccc}
\hline & Standard treatment & Standard treatment + TCL \\
\hline \multicolumn{3}{c}{ Mercury intoxication score, median (ranges) } \\
Baseline & $5(4-6)$ & $6(5-8)$ \\
Day 30 & $3(0-5)$ & $2.5(1-5)$ \\
Day 60 & $2.5(0-4)$ & $2.5(1-5)$ \\
& Physical fatigue score, median (ranges) \\
Baseline & $8(8)$ & $8(8)$ \\
Day 30 & $7(0-8)$ & $5.5(0-7)$ \\
Day 60 & $5.5(0-8)$ & $3(0-8)$ \\
& Mental fatigue score, median (ranges) \\
Baseline & $5(5)$ & $5(5)$ \\
Day 30 & $4.5(0-5)$ & $3(0-5)$ \\
Day 60 & $4.5(0-5)$ & $3(0-5)$ \\
\hline
\end{tabular}

TCL - a combination of Silybum marianum (172 mg), N-Acetyl-Cysteine (200 mg), L-Glutathione (25 mg), Vitamin C (120 mg), Selenium $(100 \mu \mathrm{g})$, Helianthus tuberosus, Taraxacum officinale, Schisandra chinensis, Zingiber officinale, Citrus paradise

Another important aspect is that chelation therapy has its own side effects. 2,3-dimercapto-1-propanesulfonic acid has a good affinity for mercury, but patients with gluthathione S-transferase enzyme abnormalities may have a cumulative benefit receiving glutathione precursors [15].Some plants possess the ability to uptake toxic agents from the environment or to increase elimination of mercury from the muscles, ligaments, connective tissue, and bone [16].

The study creates a perspective of including plant extracts in anti-toxic treatment in order to reduce symptoms associated with low level mercury exposure, which is nowadays connected with modern food behaviour.

\section{Conclusions}

In conclusion, this study provides evidence regarding some herbal extracts that may play a protective role against mercury toxicity, improving clinical scores when compared to standard treatment. More trials are needed to establish an integrative approach against mercury poisoning and future investigations could be performed in order to evaluate prevention capacity of natural extracts against harmful mercury exposure.

\section{Conflict of interest}

The authors declare no conflict of interest.

\section{References}

1. Ye BJ, Kim BG, Jeon MJ, Kim SY, Kim HC, Jang TW, Chae HJ, Choi WJ, Ha MN, Hong YS, Evaluation of mercury exposure level, clinical diagnosis and treatment for mercury intoxication. Ann of Occup and Environ Med., 2016; 28: 1-8.

2. Posin SL, Sharma S, Mercury Toxicity. In: StatPearls. Treasure Island (FL): StatPearls Publishing; 2019, www.ncbi.nlm.nih.gov.

3. Ţincu RC, Cobilinschi C, Ghiorghiu Z, Macovei RA, Acute mercury poisoning from occult ritual use. Rom J Anaesth Intensive Care., 2016; 23(1): 73-76.

4. Mititelu M, Ghica M, Ioniță AC, Moroşan E, The influence of heavy metals contamination in soil on the composition of some wild edible mushrooms. Farmacia, 2019; 67(3): 398-404

5. Ballatori N, Lieberman MW, Wang W, N-acetylcysteine as an antidote in methylmercury poisoning. Environ Health Perspect, 1998; 106(5): 267-271.

6. Unsal V, Natural phytotherapeutic antioxidants in the treatment of mercury intoxication-a review. $A d v$ Pharm Bull., 2018; 8(3): 365-376.

7. Schutzmeier P, Baquerizo AF,Castillo-Tandazo W, Focil N, Bose-O'Reilly S, Efficacy of N,N‘bis-(2mercaptoethyl) isophthalamide on mercury intoxication: a randomized controlled trial. Environ Health., 2018; 17: $1-15$

8. Bose-O'Reilly S, Bernaudat L, Siebert U, Roider G, Nowak D, Drasch G, Signs and symptoms of mercuryexposed gold miners. Int J Occup Med Environ Health., 2017; 30(2): 249-269.

9. Doering S, Bose-O'Reilly S, Berger U, Essential indicators identifying chronic inorganic mercury intoxication: Pooled analysis across multiple crosssectional studies. PLoS One, 2016; 11(8): 1-17.

10. Wessely SPR, Fatigue syndrome. In: Scales and Scores in Neurology. Edited by Masur HPK, Althoff S, Oberwittler C, Heil U, Hundenborn S, Nedjat S, Papke H, Speight I, Sträter R, Vollmer-Haase J. Stuttgart: Georg Thieme Verlag; 2000.

11. Kasote DM, Hegde MV, Katyare SS, Mitochondrial dysfunction in psychiatric and neurological diseases: 
Cause(s), consequence(s), and implications of antioxidant therapy. Biofactors, 2013; 39(4): 392-406.

12. Joshi D, Srivastav SK, Belemkar S, Dixit VA, Zingiber officinale and 6-gingerol alleviate liver and kidney dysfunctions and oxidative stress induced by mercuric chloride in male rats: A protective approach. Biomed Pharmacother., 2017; 91: 645-655.

13. Mehrandish R, Rahimian A, Shahriary A, Heavy metals detoxification: A review of herbal compounds for chelation therapy in heavy metals toxicity. $J$ Herbmed Pharmacol., 2019; 8(2): 69-77.
14. Dițescu C, Băbeanu N, Olariu L, Dumitriu B, Papacocea R, Popa O, Velescu BS, Antioxidant effects on vascular endothelial cells induced by active components of Punica granatum and Amaranthus sp. extracts. Farmacia, 2019; 67(4): 722-728.

15. Bernhoft RA, Buttar RA, Autism: a multi-system oxidative and inflammatory disorder. Townsend Letter, 2008: 86-90.

16. Tsezos M, Biosorption of Heavy Metals. In:Volesky B, Biosorption of Radioactive Species editor. Boston: CRC Press; 1990. 